ARTICLE

Received 4 Mar 2015 | Accepted 3 Sep 2015 | Published 9 Oct 2015

DOI: $10.1038 /$ ncomms 9550

\title{
Selective hydrogenation of 1,3-butadiene on platinum-copper alloys at the single-atom limit
}

Felicia R. Lucci ${ }^{1, \star}$, Jilei Liu ${ }^{2, \star}$, Matthew D. Marcinkowski ${ }^{1}$, Ming Yang ${ }^{2}$, Lawrence F. Allard ${ }^{3}$, Maria Flytzani-Stephanopoulos ${ }^{2} \&$ E. Charles H. Sykes ${ }^{1}$

Platinum is ubiquitous in the production sectors of chemicals and fuels; however, its scarcity in nature and high price will limit future proliferation of platinum-catalysed reactions. One promising approach to conserve platinum involves understanding the smallest number of platinum atoms needed to catalyse a reaction, then designing catalysts with the minimal platinum ensembles. Here we design and test a new generation of platinum-copper nanoparticle catalysts for the selective hydrogenation of 1,3-butadiene, an industrially important reaction. Isolated platinum atom geometries enable hydrogen activation and spillover but are incapable of $\mathrm{C}-\mathrm{C}$ bond scission that leads to loss of selectivity and catalyst deactivation. $\gamma$-Alumina-supported single-atom alloy nanoparticle catalysts with $<1$ platinum atom per 100 copper atoms are found to exhibit high activity and selectivity for butadiene hydrogenation to butenes under mild conditions, demonstrating transferability from the model study to the catalytic reaction under practical conditions.

\footnotetext{
${ }^{1}$ Department of Chemistry, Tufts University, 62 Talbot Avenue, Medford, Massachusetts 02155, USA. ${ }^{2}$ Department of Chemical and Biological Engineering, Tufts University, 4 Colby Street, Medford, Massachusetts 02155, USA. ${ }^{3}$ Materials Science and Technology Division, Oak Ridge National Laboratory, PO Box 2008 MS-6064, Oak Ridge, Tennessee 37831, USA. * These authors contributed equally to this work. Correspondence and requests for materials should be addressed to M.F.-S. (email: maria.flytzani-stephanopoulos@tufts.edu) or to E.C.H.S. (email: charles.sykes@tufts.edu).
} 
P latinum $(\mathrm{Pt})$ is one of the most widely used transition metal catalysts due to its superior catalytic performance for both oxidation and hydrogenation reactions. It is used extensively in electrochemical and heterogeneous catalysts with applications in fuel cells, automotive catalytic converters and industrial hydrocarbon cracking processes ${ }^{1,2}$. Pt will also undoubtedly play a large role in the ongoing development of clean energy technologies. Despite its favourable reactivity, there are two major drawbacks of Pt catalysts. First, Pt is very expensive and scarce in nature, which imposes major limitations on its future role in catalysis. Second, $\mathrm{Pt}$ is susceptible to carbon monoxide (CO) poisoning in polymer electrolyte membrane (PEM) fuel cells because CO binds strongly to metallic $\mathrm{Pt}^{3,4}$. Therefore, a key step towards the next-generation catalysts will be the development of hybrid systems that retain the high activity of $\mathrm{Pt}$ while improving its selectivity and increasing its tolerance to $\mathrm{CO}$ poisoning.

One approach is to design catalysts that contain only the $\mathrm{Pt}$ sites necessary to perform or to assist a target reaction. Recently 'single-site heterogeneous catalysts' containing atomically dispersed active metal species have been shown to be effective in catalysing a number of reactions ${ }^{5}$. Single-site $\mathrm{Pt}$ and $\mathrm{Au}$ cations stabilized by -O- linkages on various supports with vicinal $-\mathrm{OH}$ groups have been identified as the active sites for the water-gas shift reaction ${ }^{6,7}$. In a similar fashion, isolated precious metal- $\mathrm{O}_{x}$ species on various support matrices have shown superior activity for $\mathrm{CO}$ oxidation $^{8}$, and the steam reforming of methanol ${ }^{9,10}$. Atomically dispersed $\mathrm{Au}$ in metallic $\mathrm{Ni}$ has been shown to markedly suppress carbon deposition in the steam reforming of methane $e^{11}$, whereas isolated Pd atoms in a metallic copper host catalyse selective hydrogenation reactions ${ }^{12-14}$. Although Pt and Pd are often interchangeable in terms of catalytic activity, they have different physical properties that impact their alloying behaviour, surface segregation and electronic structure that can potentially impact their ability to activate $\mathrm{H}_{2}$ and catalyse hydrogenation reactions ${ }^{15-19}$. Pt/Cu bimetallic alloys offer an alternative method for reducing the amount of $\mathrm{Pt}$ and potentially enhancing catalyst selectivity for partial hydrogenation reactions ${ }^{20-23}$, but to date it has not been reported that single metallic Pt atoms are capable of such chemistry. Theoretical work has shown that by simultaneously optimizing the activation of reactants and binding strength of intermediates, the catalyst activity for hydrogenation reactions should be controllable ${ }^{24}$.

Herein we show that very low concentrations of individual, isolated $\mathrm{Pt}$ atoms in a $\mathrm{Cu}$ surface catalyse the industrially important butadiene hydrogenation reaction with high selectivity to butenes. Butadiene poisons polymerization catalysts even at low concentrations ( $<10$ p.p.m.) in industrial alkene streams ${ }^{25}$. Of particular interest is the butadiene impurity in propene feedstocks used to produce 42.3 million tons of polypropylene annually ${ }^{26}$. The selective hydrogenation of butadiene to butene serves to increase the purity of alkene feedstocks without reducing their overall concentration. Therefore, catalysts that selectively hydrogenate butadiene to butenes and prevent the hydrogenation of butenes to butane are of great interest. It has been proposed that the observed product distribution is controlled by the adsorption energy of butadiene to the catalytic surface and weaker binding is known to direct the product distribution in favour of the formation of butenes ${ }^{27,28}$. Our surface science experiments show that $\mathrm{Cu}$ binds butadiene weaker than $\mathrm{Pt}$, but the dissociation of molecular $\mathrm{H}_{2}$ on $\mathrm{Cu}$ surfaces and nanoparticle (NP) systems is often the rate limiting step. We use highresolution microscopy to interrogate the atomic geometry of $\mathrm{Pt} /$ $\mathrm{Cu}$ alloys and discovered the minimum ensemble of $\mathrm{Pt}$, a single atom, embedded in $\mathrm{Cu}(111)$ single crystal surface will dissociate $\mathrm{H}_{2}$ thus enabling selective hydrogenation reactions. Our surface science experiments reveal that isolated $\mathrm{Pt}$ atom geometries, unlike continuous Pt ensembles, exhibit weak binding of $\mathrm{CO}$ and maintain activity after many hydrogenation cycles. Guided by these model catalyst experiments, we prepare highly diluted $\mathrm{Pt} /$ $\mathrm{Cu}$ NPs using this single-atom alloy (SAA) principle ${ }^{12,13}$. NP Cu catalysts, with $\mathrm{Pt}$ as the minority species, are found to exhibit high activity and selectivity for butadiene hydrogenation to butenes under relatively mild conditions.

\section{Results}

Hydrogen uptake and desorption from $\mathrm{Pt} / \mathrm{Cu}(111)$ surfaces. Model $\mathrm{Pt} / \mathrm{Cu}$ surfaces with a range of $\mathrm{Pt}$ coverages were prepared using physical vapour deposition of $\mathrm{Pt}$ onto a clean $\mathrm{Cu}(111)$ surface held at $380 \mathrm{~K}$. Scanning tunnelling microscopy (STM) imaging (Fig. 1b) shows that at low Pt coverages (0.02 monolayer $(\mathrm{ML})$ ), Pt atoms exist as individual, isolated species substituted in the $\mathrm{Cu}$ surface lattice, which we refer to as a SAA ${ }^{19}$. The STM images indicate that $\mathrm{Pt}$ atoms incorporate both directly into $\mathrm{Cu}(111)$ terraces and in areas above surface step edges via place exchange. Even in regions of higher local concentration near step edges, the Pt atoms are always isolated from one another and do not form dimer or trimer clusters. This high dispersion of individual $\mathrm{Pt}$ atoms is driven by the negative mixing enthalpy of $\mathrm{Pt}$ in $\mathrm{Cu}$ and elastic strain relief of incorporating a larger $\mathrm{Pt}$ atom into a smaller $\mathrm{Cu}$ lattice. ${ }^{15}$

By quantifying surface coverages of both $\mathrm{Pt}$ and $\mathrm{H}$, our temperature-programmed desorption (TPD) experiments (Fig. 1a) reveal that trace amounts of $\mathrm{Pt}$ make $\mathrm{H}$ available on the more inert $\mathrm{Cu}$ surface by dissociating $\mathrm{H}_{2}$ and allowing spillover of $\mathrm{H}$ atoms to $\mathrm{Cu}$ sites. Importantly, the $\mathrm{H}_{2}$ desorption temperature on the $\mathrm{Pt} / \mathrm{Cu}(111)$ SAA of $230 \mathrm{~K}$ is significantly lower than $\mathrm{H}_{2}$ desorption from either a $\mathrm{Pt}(111)$ or $\mathrm{Cu}(111)$ surfaces, which occurs at $\sim 300 \mathrm{~K}$ (refs 29-31), meaning that the $\mathrm{H}$ atoms also recombine and desorb from the $\mathrm{Pt}$ atom sites. This
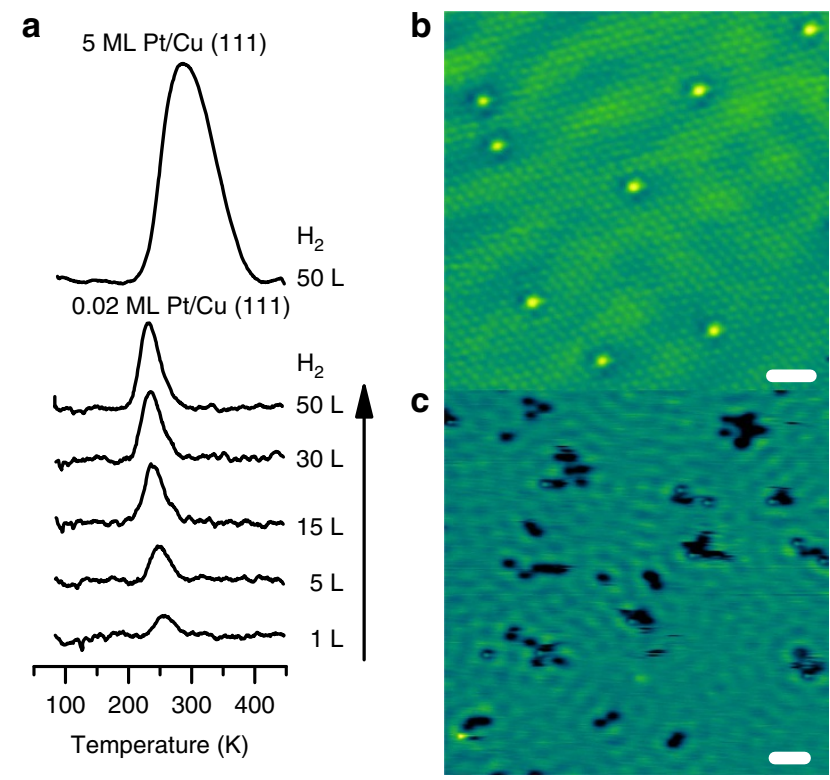

Figure 1 | Hydrogen dissociation and spillover on a Pt/Cu(111) SAA. (a) TPD traces of $\mathrm{H}_{2}$ uptake on $0.02 \mathrm{ML}$ and $5 \mathrm{ML} \mathrm{Pt} / \mathrm{Cu}(111)$ surface exposed to $\mathrm{H}_{2}$ at $85 \mathrm{~K}$. Gas exposures are quoted in Langmuirs (L). (b) STM image of $0.02 \mathrm{ML} \mathrm{Pt/Cu(111)} \mathrm{SAA} \mathrm{surface} \mathrm{where} \mathrm{the} \mathrm{Pt} \mathrm{atoms} \mathrm{appear} \mathrm{as}$ isolated protrusions substituted into the $\mathrm{Cu}(111)$ surface. Scale bar, $1 \mathrm{~nm}$. (c) STM image showing $\mathrm{H}$ atom spillover onto $\mathrm{Cu}$ in which the $\mathrm{H}$ atoms appear as depressions and cluster into small mobile islands. Pt sites appear in STM images as protrusions. Scale bar, $3 \mathrm{~nm}$. 
is consistent with the principle of microscopic reversibility that states the forward and reverse reactions follow the same lowest energy pathway. With increasing exposure to $\mathrm{H}_{2}$, the desorption temperature shifts to lower temperatures characteristic of second-order desorption kinetics. Therefore, the $\mathrm{Pt}$ atoms in $\mathrm{Cu}$ act as both entrance and exit sites for $\mathrm{H}_{2}$ dissociation and recombination, respectively. Calculations predict that Pt exhibits a negligible barrier for $\mathrm{H}_{2}$ dissociative adsorption, which is consistent with the facile dissociative adsorption of $\mathrm{H}_{2}$ that we observe at $85 \mathrm{~K}$ (ref. 32). Notably, the concentration of $\mathrm{H}_{2}$ desorbing from the surface is much higher than the Pt coverage, demonstrating that the $\mathrm{H}$ atoms must spill over from the Pt sites to $\mathrm{Cu}$. Low-temperature STM (LT-STM) allows us to directly image these $\mathrm{H}$ atoms. STM images of $\mathrm{Pt} / \mathrm{Cu}(111)$ SAA surfaces exposed to $\mathrm{H}_{2}$ show mobile depressions on the $\mathrm{Cu}$ surface that Jewell et al..$^{33}$ previously assigned as $\mathrm{H}$ atoms diffusing across a $\mathrm{Cu}$ surface. The presence of $\mathrm{H}$ atoms on $\mathrm{Cu}(111)$ demonstrates that $\mathrm{H}$ atoms do indeed spill over onto the $\mathrm{Cu}$ surface (Fig. 1c). This spillover process allows for an increase in weakly bound $\mathrm{H}$ on $\mathrm{Cu}\left(\sim 20 \mathrm{~kJ} \mathrm{~mol}^{-1}\right.$; ref. 34), which is a prerequisite for selective hydrogenation chemistry.

The low-temperature desorption of $\mathrm{H}_{2}$ from the $\mathrm{Pt} / \mathrm{Cu}(111)$ SAA surface is a result of a decrease in the $\mathrm{H}_{2}$ recombination barrier as compared with a $\mathrm{Cu}$ surface and a decrease in $\mathrm{H}$ atom binding energy compared with a pure $\mathrm{Pt}$ surface. These experimental results are consistent with theoretical studies that predict a minimal activation energy $(<0.05 \mathrm{eV})$ for $\mathrm{H}_{2}$ dissociation at individual, isolated $\mathrm{Pt}$ sites in $\mathrm{Cu}$ and much weaker binding of $\mathrm{H}$ atoms to the $\mathrm{Cu}$ surface as opposed to pure $\mathrm{P}^{32,35}$. The weaker binding of $\mathrm{H}$ atoms at the single $\mathrm{Pt}$ atom dissociation sites compared with $\mathrm{Pt}(111)$ results from the preferential adsorption of $\mathrm{H}$ at threefold hollow sites, which in the SAAs are composed of one $\mathrm{Pt}$ atom and two $\mathrm{Cu}$ atoms. By combining complementary energetic landscapes for $\mathrm{H}_{2}$ dissociation and spillover, we later show that $\mathrm{Pt} / \mathrm{Cu}$ bimetallic catalysts exhibit enhanced reactivity since Pt readily activates $\mathrm{H}_{2}$ and $\mathrm{Cu}$ exhibits weak binding of reaction intermediates. Thus, the $\mathrm{Pt} / \mathrm{Cu}$ bimetallic combination addresses both the reduced selectivity of Pt catalysts and the barrier for $\mathrm{H}_{2}$ activation on $\mathrm{Cu}$ (refs 30,36).

In addition, our experiments reveal that $\mathrm{Pt} / \mathrm{Cu}(111)$ SAAs bind $\mathrm{CO}$ significantly weaker than $\mathrm{Pt}$ as evidenced by the lower desorption temperature of $\mathrm{CO}$ from single $\mathrm{Pt}$ atoms $(350 \mathrm{~K})$ compared with $\mathrm{Pt}(111)$ (ref. 32) (450 K) (Supplementary Fig. 1 and Supplementary Note 1). This result holds great promise for the utility of $\mathrm{Pt} / \mathrm{Cu}$ SAAs given problems such as $\mathrm{CO}$ poisoning of the Pt anodes of PEM fuel cells ${ }^{4}$.

Butadiene hydrogenation on $\mathrm{Pt} / \mathrm{Cu}(\mathbf{1 1 1})$ alloys. To probe the chemical reactivity of $\mathrm{Pt} / \mathrm{Cu}$ SAAs, we performed TPD/reaction $(\mathrm{TPD} / \mathrm{R})$ studies on the model catalyst systems. Figure $2 \mathrm{a}$ shows TPD/R traces resulting from adsorption of $50 \mathrm{~L} \mathrm{H}_{2}$ (which results in $0.2 \mathrm{ML}$ of adsorbed $\mathrm{H}$ atoms $\left(\mathrm{H}_{\mathrm{a}}\right)$ ) and $0.1 \mathrm{~L}$ butadiene $(0.2 \mathrm{ML})$ on a $0.02 \mathrm{ML} \mathrm{Pt} / \mathrm{Cu}(111) \mathrm{SAA}$. The sole product of coadsorption of $\mathrm{H}_{\mathrm{a}}$ and butadiene is butenes at $25 \%$ conversion with no detectable yield of butane. The hydrogenation reaction is facile on the SAA as evidenced by reactively formed butenes desorbing from the surface below room temperature $(240 \mathrm{~K})$. Unreacted butadiene desorbs from $\mathrm{Cu}$ terraces $(220 \mathrm{~K})$, Pt sites $(290 \mathrm{~K})$ and $\mathrm{Cu}$ steps $(330 \mathrm{~K})$, and unreacted $\mathrm{H}_{2}$ desorbs from Pt sites $(230 \mathrm{~K})$ (Supplementary Figs 2 and 3, and Supplementary Note 2). The desorption temperature of these unreacted species is consistent with desorption from a clean $\mathrm{Pt} / \mathrm{Cu}(111)$ surface, demonstrating that the co-adsorption of butadiene and $\mathrm{H}_{\mathrm{a}}$ does not alter the desorption behaviour of either species. In the absence of $\mathrm{H}_{\mathrm{a}}$, butadiene reversibly adsorbs and desorbs from the surface

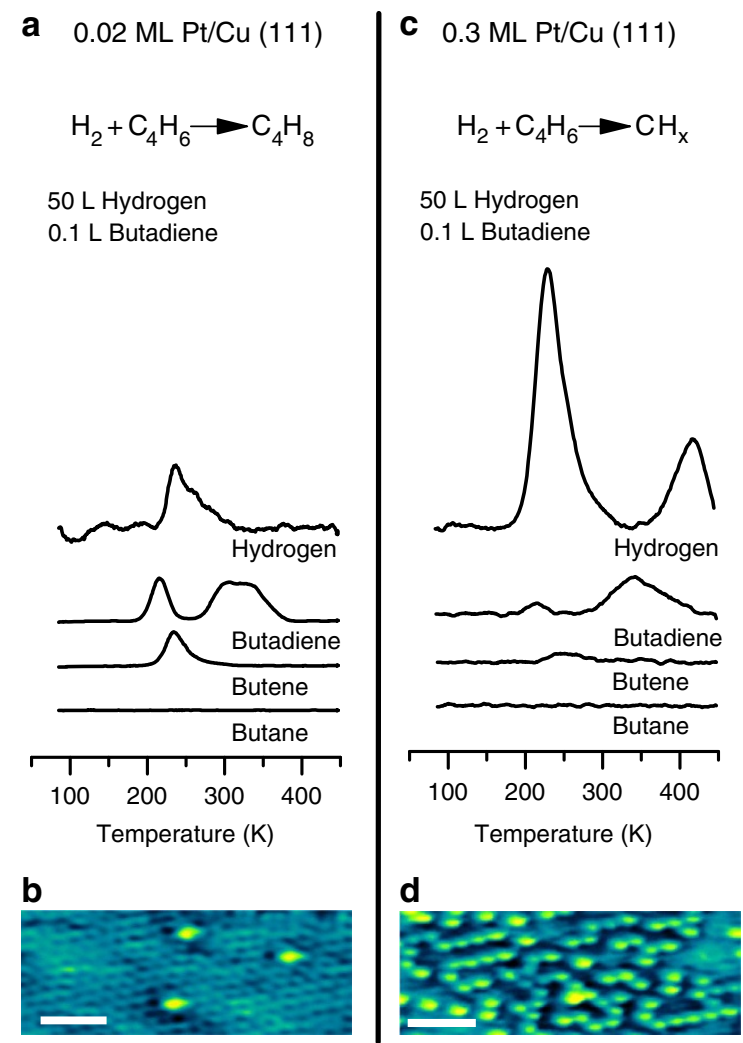

Figure 2 | Selective hydrogenation of butadiene on Pt/Cu(111) SAAs versus larger Pt ensembles. TPD/R traces from the adsorption of $\mathrm{H}_{2}$ and butadiene on (a) $0.02 \mathrm{ML} \mathrm{Pt} / \mathrm{Cu}(111) \mathrm{SAA}$ and (c) $0.3 \mathrm{ML} \mathrm{Pt} / \mathrm{Cu}(111)$. STM image of (b) $0.02 \mathrm{ML}$ and (d) $0.3 \mathrm{ML} \mathrm{Pt} / \mathrm{Cu}(111)$. Scale bars, $1 \mathrm{~nm}$.

without decomposing or inducing self-hydrogenation to unwanted butane (Supplementary Fig. 3). Reactively formed butenes desorb at the same temperature as adsorbed 1-butene (Supplementary Fig. 4), indicating that the reaction is desorption rate limited and the selective hydrogenation must occur at a temperature below $240 \mathrm{~K}$ (refs 37-39). Desorption of butane is never observed and co-adsorption of $\mathrm{H}_{\mathrm{a}}$ and 1-butene did not yield the fully hydrogenated product butane (Supplementary Fig. 5), indicating that weak binding to $\mathrm{Cu}$ enables selective hydrogenation to the desired product.

Increasing the concentration of $\mathrm{Pt}$ to $0.3 \mathrm{ML}$ decreased the selectivity of the surface to butenes. With increased Pt content, we predominantly observe decomposition of hydrocarbons resulting in surface-bound hydrocarbon fragments as evidenced by desorption of $\mathrm{H}_{2}$ at higher temperatures (Fig. 2c) ${ }^{40}$. High-temperature desorption of $\mathrm{H}_{2}(420 \mathrm{~K})$ is indicative of the decomposition of butadiene and butenes into surface $\mathrm{CH}_{x}$ fragments that further decompose to $\mathrm{C}$ and release additional $\mathrm{H}_{2}$ at higher temperatures as previously observed for decomposed butenes on Pd model catalysts ${ }^{40}$. STM images of $0.3 \mathrm{ML}$ $\mathrm{Pt} / \mathrm{Cu}(111)$ reveal the cause of this effect; in addition to single Pt atoms, the 0.3-ML Pt surface is composed of extended linear chains (2-10 atoms) of Pt atoms (Fig. 2d). Unlike individual Pt atoms, these larger $\mathrm{Pt}$ ensembles within the $\mathrm{Cu}$ matrix are capable of breaking $\mathrm{C}-\mathrm{C}$ and $\mathrm{C}-\mathrm{H}$ bonds that leads to decomposition and active site poisoning. These Pt sites exhibit reduced selectivity similar to Pt(111) on which the decomposition of butadiene is preferred over hydrogenation due to strong binding of butadiene to $\mathrm{Pt}(111)$ and facile decomposition ${ }^{41-44}$.

To determine the active sites for hydrogenation, $\mathrm{CO}$ was used to selectively block Pt sites as the hydrogenation was performed. 
a $0.02 \mathrm{ML} \mathrm{Pt} / \mathrm{Cu}(111)$ $50 \mathrm{~L}$ Hydrogen $0.1 \mathrm{~L}$ Butadiene

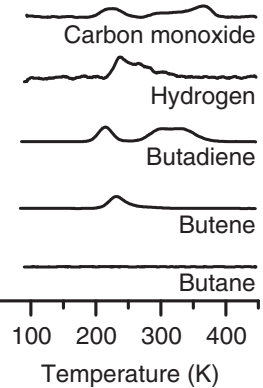

b $0.02 \mathrm{ML} \mathrm{Pt/Cu}(111)$ 50 L Hydrogen $0.1 \mathrm{~L}$ Carbon monoxide 0.1 L Butadiene
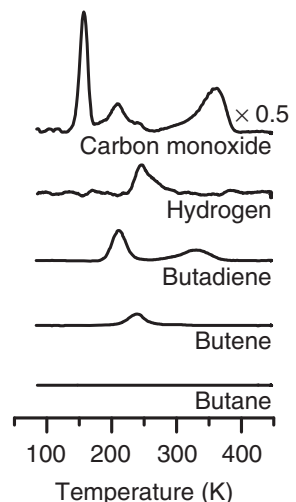

Figure 3 | Butadiene hydrogenation in the presence of $\mathrm{CO}$. TPD/R traces for the co-adsorption of $\mathrm{H}_{2}$ and butadiene (a) without and (b) with $\mathrm{CO}$ on $0.02 \mathrm{ML} \mathrm{Pt} / \mathrm{Cu}(111) . \mathrm{H}_{2}$ was adsorbed on the surface before adsorption of $\mathrm{CO}$.

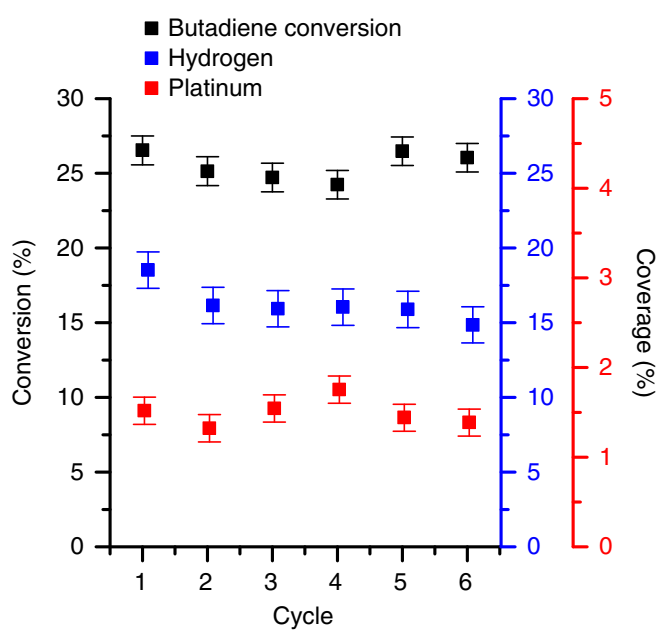

Figure 4 | Repeated cycles of butadiene hydrogenation on a Pt/Cu(111) SAA reveal no loss in activity. Multiple cycles of TPD/R after the co-adsorption $50 \mathrm{~L} \mathrm{H}_{2}+0.1 \mathrm{~L}$ butadiene, followed by TPD of $50 \mathrm{~L} \mathrm{H}_{2}$ and then TPD of $1 \mathrm{~L} \mathrm{CO}$ on $0.02 \mathrm{ML}$ Pt/Cu(111) SAA. Multiple co-adsorptions of $\mathrm{H}_{2}$ and butadiene lead to no decrease in the amount of butenes produced. The Pt atom concentration in the surface after each reaction cycle was quantified by $\mathrm{CO}$ titration. In each reaction cycle, the temperature was ramped from 85 to $450 \mathrm{~K}$. Error bars are 1s.d. of the data.

First, $\mathrm{H}$ was adsorbed onto a $\mathrm{Pt} / \mathrm{Cu}(111)$ SAA and then small amounts of $\mathrm{CO}$ were adsorbed (Fig. 3). Owing to the stronger binding energy of $\mathrm{CO}$ to $\mathrm{Pt}$ than $\mathrm{Cu}, \mathrm{CO}$ selectively adsorbs atop to the isolated $\mathrm{Pt}$ atoms ${ }^{45,46}$. $\mathrm{H}$ was adsorbed onto the surface before $\mathrm{CO}$ since $\mathrm{CO}$ blocks the adsorption of $\mathrm{H}$. The surface was then exposed to butadiene and the temperature was ramped to perform the hydrogenation reaction. Since CO desorbs from $\mathrm{Pt}$ sites at higher temperature $(350 \mathrm{~K})$ than butenes or $\mathrm{H}_{2}, \mathrm{CO}$ inhibits any hydrogenation from occurring at the Pt sites. $\mathrm{CO}$ also blocks the adsorption of butadiene at $\mathrm{Pt}$ sites as seen by the disappearance of its desorption peak at $290 \mathrm{~K}$. Our results indicate that the conversion of butadiene to butenes is unaffected by the $\mathrm{CO}$ adsorption at the $\mathrm{Pt}$ atom sites, meaning that the selective hydrogenation of butadiene occurs predominately on the $\mathrm{Cu}$ sites.
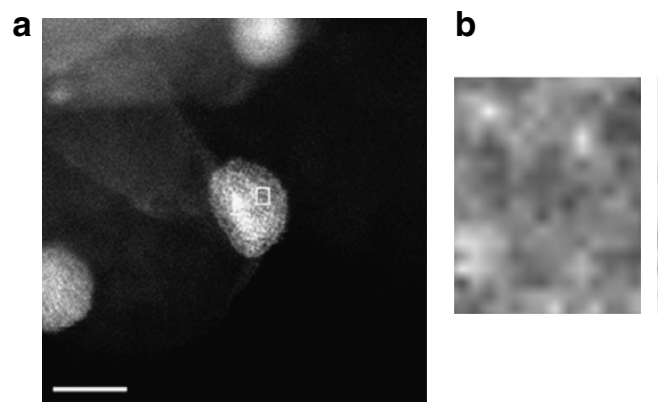

C
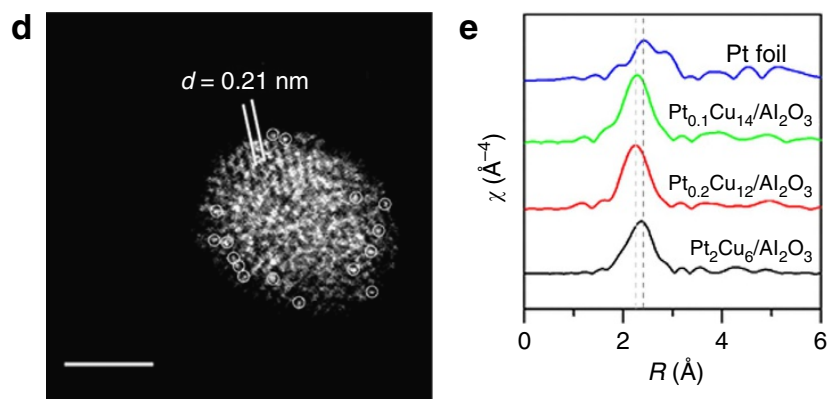

Figure 5 | Characterization of Pt/Cu SAA NPs. (a-d) HAADF-STEM images with (c) coloured intensity map from selected region, and (e) EXAFS $k^{3}$-weighted Fourier transforms. (a,d) Typical regions of the sample $\mathrm{Pt}_{0.1} \mathrm{Cu}_{14} / \mathrm{Al}_{2} \mathrm{O}_{3}$, showing $\mathrm{Cu}$ metal particles with isolated $\mathrm{Pt}$ atoms. Isolated Pt atoms are highlighted with circles. The lattice spacing of $\mathrm{Cu}$ is $0.21 \mathrm{~nm}$. Scale bars, $5 \mathrm{~nm}$ (a) and $2 \mathrm{~nm}$ (d). (b) Enlarged image and (c) colorized intensity map of highlighted region showing isolated Pt atoms. (e) EXAFS data were collected at Pt- $\mathrm{L}_{\text {III }}$ edge at room temperature from Pt foil and in $\mathrm{H}_{2}$ atmosphere at $\mathrm{Pt}-\mathrm{L}_{\text {III }}$ edge at room temperature from pre-reduced $\mathrm{Pt}_{0.1} \mathrm{Cu}_{14} / \mathrm{Al}_{2} \mathrm{O}_{3}, \mathrm{Pt}_{0.2} \mathrm{Cu}_{12} / \mathrm{Al}_{2} \mathrm{O}_{3}$ and $\mathrm{Pt}_{2} \mathrm{Cu}_{6} / \mathrm{Al}_{2} \mathrm{O}_{3}$.

$\mathrm{Pt} / \mathrm{Cu}(111)$ SAAs exhibit excellent stability after multiple TPD/R cycles as shown by the steady and selective conversion of butadiene to butenes. Cycles of the co-adsorption of hydrogen and butadiene followed by $\mathrm{CO}$ titration and $\mathrm{H}_{2}$ uptake showed no change in reactivity (Fig. 4). After six cycles, the conversion of butadiene to butenes remained constant at $25 \pm 1 \%$ as determined by the amount of butenes desorbing at $240 \mathrm{~K}$. The number of $\mathrm{Pt}$ atoms in the surface was also quantified via $\mathrm{CO}$ titration between each reaction. After each TPD/R cycle, the concentration of $\mathrm{Pt}$ atoms in the surface layer was $1.4 \pm 0.2 \%$, consistent with the number of $\mathrm{Pt}$ atoms present prior to each hydrogenation reaction. Since the Pt atoms serve as the entrance routes of $\mathrm{H}_{\mathrm{a}}$ onto the surface, the ability for the surface to uptake $\mathrm{H}_{\mathrm{a}}$ remained constant at $15 \pm 1 \%$. Loss of $\mathrm{Pt}$ sites or decrease in $\mathrm{H}_{2}$ activation was not observed because $\mathrm{Pt}$ atoms are neither poisoned by decomposition of hydrocarbon fragments nor lost by sub-surface migration. Since multiple hydrogenation runs result in no decrease in activity or selectivity, single isolated $\mathrm{Pt}$ atoms in $\mathrm{Cu}$ are capable of $\mathrm{H}_{2}$ activation and spillover but not of breaking $\mathrm{C}-\mathrm{C}$ bonds, thus preventing the butadiene decomposition and surface poisoning that occur at higher $\mathrm{Pt}$ coverage. The robust nature of the $\mathrm{Pt} / \mathrm{Cu}$ system further highlights the durability of SAAs.

Pt/Cu SAA NPs. Inspired by the performance and stability of highly dispersed $\mathrm{Pt}$ atoms in the model catalyst system, we applied our SAA strategy to prepare $\mathrm{Pt} / \mathrm{Cu}$ bimetallic NPs and examined them at atmospheric pressure under several realistic reaction conditions. Three different $\mathrm{Pt} / \mathrm{Cu} \mathrm{NP}$ compositions were prepared by the galvanic replacement (GR) method ${ }^{47}$, in which a controlled amount of $\mathrm{Pt}$ was exchanged with $\mathrm{Cu}$ on pre-formed $\mathrm{Cu}$ NPs supported on $\gamma-\mathrm{Al}_{2} \mathrm{O}_{3}$. Low concentrations of $\mathrm{Pt}$ in 
solution form SAA $\mathrm{Pt}_{0.1} \mathrm{Cu}_{14} / \mathrm{Al}_{2} \mathrm{O}_{3}$ and $\mathrm{Pt}_{0.2} \mathrm{Cu}_{12} / \mathrm{Al}_{2} \mathrm{O}_{3} \mathrm{NPs}$, whereas higher concentrations of $\mathrm{Pt}$ form $\mathrm{Pt}_{2} \mathrm{Cu}_{6} / \mathrm{Al}_{2} \mathrm{O}_{3}$. A detailed description of the synthesis and characterization of all $\mathrm{Pt} / \mathrm{Cu}$ alloy NPs is given in Supplementary Figs 6-14, Supplementary Tables 1 and 2, and Supplementary Note 3.

Elemental mapping by energy dispersive X-ray spectroscopy (EDS) reveals that the $\mathrm{Pt} / \mathrm{Cu} \mathrm{NPs}$ are all bimetallic. $\mathrm{Pt}, \mathrm{Cu}, \mathrm{Al}$ and $\mathrm{O}$ elemental mapping by EDS shows that $\mathrm{Pt}$ is distributed over the $\mathrm{Cu} \mathrm{NPs}$ and is not deposited on the $\gamma-\mathrm{Al}_{2} \mathrm{O}_{3}$ support (Supplementary Fig. 10). In situ extended $\mathrm{x}$-ray absorption fine structure (EXAFS) performed at room temperature at the Pt- $\mathrm{L}_{\text {III }}$ edge reveals the coordination of $\mathrm{Pt}$ in $\mathrm{Pt} / \mathrm{Cu}$ alloys (Fig. 5e and Supplementary Table 2). No Pt-Pt bonds are detected in $\mathrm{Pt}_{0.1} \mathrm{Cu}_{14} / \mathrm{Al}_{2} \mathrm{O}_{3}$ and $\mathrm{Pt}_{0.2} \mathrm{Cu}_{12} / \mathrm{Al}_{2} \mathrm{O}_{3}$, which provides direct evidence for individual, isolated $\mathrm{Pt}$ atoms in the $\mathrm{Pt} / \mathrm{Cu}$ bimetallic NPs. The Pt/Cu first-shell interaction distance is $2.63 \AA$, which is between $\mathrm{Pt}-\mathrm{Pt}(2.77 \AA)$ and $\mathrm{Cu}-\mathrm{Cu}$ bond lengths (2.56 $\AA$; ref. 48$)$, further supporting SAA formation. The existence of Pt-Pt bonds in $\mathrm{Pt}_{2} \mathrm{Cu}_{6} / \mathrm{Al}_{2} \mathrm{O}_{3}$ suggests that $\mathrm{Pt}$ islands and/or clusters are formed in the NPs with this higher Pt loading.

Figure 5 shows aberration-corrected high-angle annular dark-field scanning transmission electron microscope (HAADFSTEM) images of $\mathrm{Pt}_{0.1} \mathrm{Cu}_{14} / \mathrm{Al}_{2} \mathrm{O}_{3}$. Aberration-corrected HAADF imaging can distinguish isolated $\mathrm{Pt}$ atoms due to differences in

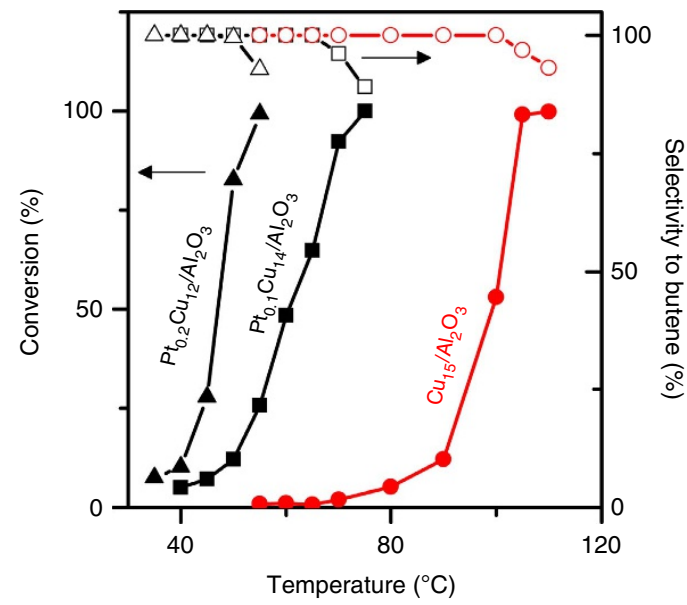

Figure 6 | Selective hydrogenation of butadiene. Hydrogenation shown as a function of temperature over $\mathrm{Cu}_{15} / \mathrm{Al}_{2} \mathrm{O}_{3}, \mathrm{Pt}_{0.1} \mathrm{Cu}_{14} / \mathrm{Al}_{2} \mathrm{O}_{3}$ and $\mathrm{Pt}_{0.2} \mathrm{Cu}_{12} / \mathrm{Al}_{2} \mathrm{O}_{3} \mathrm{NPs}\left(1,3\right.$-butadiene (1.25\%), $\mathrm{H}_{2}(20 \%)$ and He (balance), $\mathrm{GHSV}=1,200 \mathrm{~h}^{-1}$ ).
$Z$-contrast ${ }^{49,50}$. In this work, we observed a number of bright, atom-sized features within the $\mathrm{Cu}$ lattice (Fig. 5). Our EXAFS results indicate that these features are isolated $\mathrm{Pt}$ atoms in $\mathrm{Cu}$. In addition, the lattice spacing of $\mathrm{Pt} / \mathrm{Cu}$ is comparable to the pure $\mathrm{Cu}$ lattice spacing, which also supports dilute dispersion of $\mathrm{Pt}$ atoms (Fig. 5d). Variations in the background structure of the $\mathrm{Cu}$ NPs make imaging of isolated atoms difficult, but in Fig. $5 \mathrm{~d}$ the single Pt atoms are more apparent due to the uniform background ${ }^{50}$. STEM and EXAFS analyses demonstrate the formation $\mathrm{Pt} / \mathrm{Cu}$ SAA NPs, which provides a new catalytic system to study selective hydrogenation reactions.

Butadiene hydrogenation on SAA NPs. Our catalytic data reveal that adding trace amounts of Pt to Cu NPs significantly enhances hydrogenation. The butadiene hydrogenation activity and selectivity as a function of temperature on $\mathrm{Pt}_{0.1} \mathrm{Cu}_{14} / \mathrm{Al}_{2} \mathrm{O}_{3}$, $\mathrm{Pt}_{0.2} \mathrm{Cu}_{12} / \mathrm{Al}_{2} \mathrm{O}_{3}$ and $\mathrm{Cu}_{15} / \mathrm{Al}_{2} \mathrm{O}_{3} \mathrm{NPs}$ are shown in Fig. 6 and Supplementary Fig. 15. Under the conditions used, $\mathrm{Pt}_{0.1} \mathrm{Cu}_{14} / \mathrm{Al}_{2} \mathrm{O}_{3}$ has a hydrogenation reaction onset at $40^{\circ} \mathrm{C}$, which is $35^{\circ} \mathrm{C}$ lower than that of the monometallic $\mathrm{Cu}$ catalyst. The reaction rate over the $\mathrm{Pt}_{01} \mathrm{Cu}_{14} / \mathrm{Al}_{2} \mathrm{O}_{3}$ at $60^{\circ} \mathrm{C}$ is an order of magnitude higher than the monometallic $\mathrm{Cu}$ catalyst. $\mathrm{Pt}_{0.2} \mathrm{Cu}_{12} / \mathrm{Al}_{2} \mathrm{O}_{3}$ exhibits greater hydrogenation activity than $\mathrm{Pt}_{01} \mathrm{Cu}_{14} / \mathrm{Al}_{2} \mathrm{O}_{3}$ due to a higher Pt atom surface amount at the increased Pt loading. However, the selectivity remains unaffected because the $\mathrm{Pt}$ atoms continue to be isolated in $\mathrm{Pt}_{0.2} \mathrm{Cu}_{12} / \mathrm{Al}_{2} \mathrm{O}_{3}$, as found by EXAFS model fitting (Supplementary Table 2).

Notably, the SAA catalysts maintain the high selectivity to butenes exhibited by $\mathrm{Cu}$. At full conversion, there is over $90 \%$ selectivity towards butene isomers. The selectivity of SAA NPs $\left(\mathrm{Pt}_{0.1} \mathrm{Cu}_{14} / \mathrm{Al}_{2} \mathrm{O}_{3}\right.$ and $\left.\mathrm{Pt}_{0.2} \mathrm{Cu}_{12} / \mathrm{Al}_{2} \mathrm{O}_{3}\right)$ was comparable to $\mathrm{Cu}_{15} / \mathrm{Al}_{2} \mathrm{O}_{3}$, whereas $\mathrm{Pt}$ monometallic catalysts fully converted butadiene to butane under these conditions. Monometallic $\mathrm{Pt}$ is known for over-hydrogenating dienes and alkynes ${ }^{51,52}$. Therefore, by combining the hydrogen activation ability of Pt with the weak binding of butadiene on $\mathrm{Cu}$ and the latter's selectivity to butenes, $\mathrm{Pt} / \mathrm{Cu}$ SAA catalysts exhibit superior performance for this important industrial reaction (Supplementary Figs 15-20 and Supplementary Note 4). Various other alloy surfaces, including $\mathrm{Pd}-\mathrm{Au}$ and $\mathrm{Sn}-\mathrm{Pt}$, have been shown to improve selective hydrogenation reactions ${ }^{53,54}$. However, this is the first report that single $\mathrm{Pt}$ atoms can enhance selective hydrogenation reactions on a less active metal, such as $\mathrm{Cu}$.

To demonstrate the ability of $\mathrm{Pt} / \mathrm{Cu}$ SAAs to selectively hydrogenate alkadiene impurities in alkene feedstocks ${ }^{25}$, we tested the selective hydrogenation activity of $\mathrm{Pt}_{0.1} \mathrm{Cu}_{14} / \mathrm{Al}_{2} \mathrm{O}_{3}$

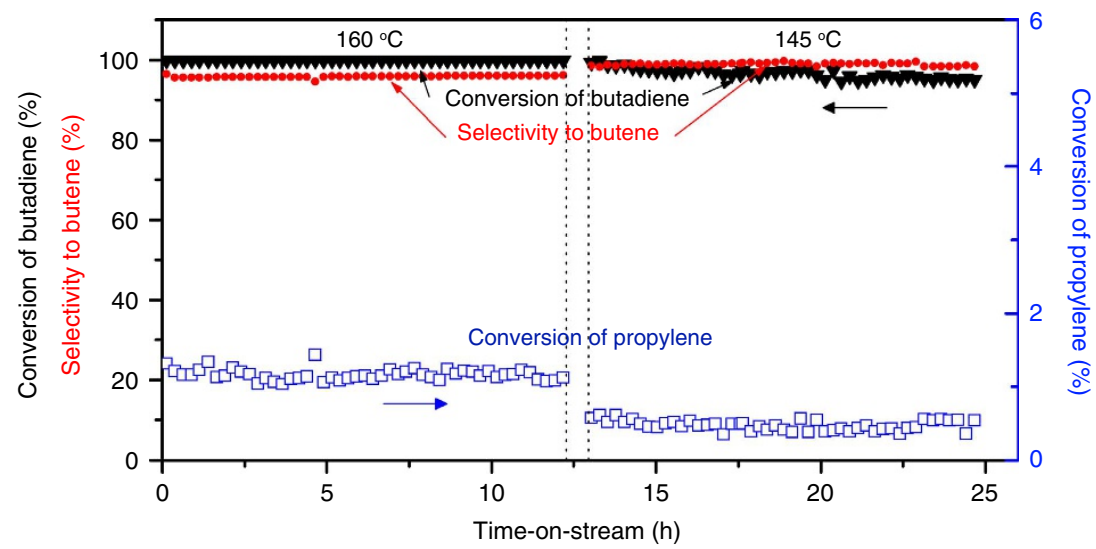

Figure 7 | Butadiene conversion in the presence of excess propylene. Conversion and selectivity in long-time steady-state selective hydrogenation of butadiene at 160 and $145^{\circ} \mathrm{C}\left(\sim 0.1 \mathrm{~g}\right.$ catalyst $\mathrm{Pt}_{0.1} \mathrm{Cu}_{14} / \mathrm{Al}_{2} \mathrm{O}_{3}$, flow rate $=50 \mathrm{ml} \mathrm{min}{ }^{-1}, 2 \%$ 1,3-butadiene, $20 \%$ propylene, $16 \% \mathrm{H}_{2}$ and balance He. $\left.\mathrm{GHSV}=12,000 \mathrm{~h}^{-1}\right)$. 
catalysts in the presence of excess propylene and found that butadiene is preferentially hydrogenated on the $\mathrm{Pt} / \mathrm{Cu}$ SAA NPs (Supplementary Fig. 19). Below $120^{\circ} \mathrm{C}$, conversion of propylene was not observed. At $100 \%$ conversion of butadiene, $<1 \%$ of propylene was converted to propane. Comparing these results with the hydrogenation activity of $\mathrm{Pt}_{0.1} \mathrm{Cu}_{14} / \mathrm{Al}_{2} \mathrm{O}_{3}$ in propylenefree condition, we found that the propylene has no effect on the activity and selectivity of $\mathrm{Pt} / \mathrm{Cu}$ SAAs for the hydrogenation of butadiene. At 160 and $145^{\circ} \mathrm{C}$, butadiene is fully converted and $>95 \%$ converted, respectively, over $\mathrm{Pt}_{0.1} \mathrm{Cu}_{14} / \mathrm{Al}_{2} \mathrm{O}_{3}$ without significant propylene hydrogenation $\left(1.2 \%\right.$ at $160^{\circ} \mathrm{C}$ and $0.5 \%$ at $145^{\circ} \mathrm{C}$ ) for $>12 \mathrm{~h}$ on-stream at each temperature (Fig. 7) demonstrating high stability of the catalysts at full conversion of butadiene.

$\mathrm{Pt} / \mathrm{Cu}$ SAAs exhibit high stability and selectivity under realistic hydrogenation conditions (Supplementary Figs 16-20). The $\mathrm{Pt} / \mathrm{Cu}$ SAAs maintain stable butadiene conversion for $>46 \mathrm{~h}$ at $160^{\circ} \mathrm{C}$ (Supplementary Fig. 16). Temperature-programmed oxidation studies of the catalysts after hydrogenation show negligible $\mathrm{CO}_{2}$ formation (Supplementary Fig. 20) demonstrating the robustness of SAA catalysts to butadiene decomposition, oligomerization and coke formation. Based on our model catalyst studies, the increase in the selectivity of SAAs is due to the inhibition of hydrocarbon decomposition commonly observed with Pt catalysts because SAAs do not offer extended Pt ensembles where these unfavourable reactions occur. In addition, it is known that $\mathrm{Cu}$ or $\mathrm{Pd}$ catalysts for diene and alkyne hydrogenation are affected by oligomer formation at mild temperatures, which leads to instability in their hydrogenation activity $^{55}$. By running the reaction at higher temperatures, we do not observe any instability in the catalysts due to oligomerization (Supplementary Fig. 16). We found that after performing the reaction at near ambient temperatures, the hydrogenation activity declines due to adsorption of hydrocarbon species. However, the activity can be fully recovered by heating in $\mathrm{H}_{2}$ at $350^{\circ} \mathrm{C}$, which effectively desorbs the hydrocarbons (Supplementary Fig. 17). Running at the higher temperatures shown in Fig. 7 preserved the catalyst activity without affecting its selectivity.

\section{Discussion}

In this work, surface science and atomic resolution microscopy studies of the selective hydrogenation of butadiene to butenes on model $\mathrm{Pt} / \mathrm{Cu}(111)$ alloy surfaces have shown that individual, isolated $\mathrm{Pt}$ atoms in the $\mathrm{Cu}(111)$ surface are all that is required to ensure stable activity and $100 \%$ selectivity. We have extended these findings to realistic pressures (1 bar) by synthesizing and testing $\mathrm{Pt} / \mathrm{Cu}$ SAA NP catalysts. At low loadings, Pt exists as individual, isolated atoms substituted into the $\mathrm{Cu}(111)$ surface. These single Pt atoms activate the dissociation and spillover of $\mathrm{H}$ to $\mathrm{Cu}$. The weak binding of butadiene to $\mathrm{Cu}$ allows for the highly selective hydrogenation to butenes. No decomposition or poisoning of these alloys was observed, which can be attributed to the lack of extended Pt surface sites. At higher Pt content in $\mathrm{Pt} / \mathrm{Cu}$ alloy surfaces, we directly visualized extended $\mathrm{Pt}$ ensembles responsible for the reduced selectivity. Isolated Pt atoms also bind CO significantly more weakly than metallic $\mathrm{Pt}$, which is an important consideration in many Pt-catalysed reactions. This combined model system/NP catalyst strategy is a powerful approach to the design of new alloy catalysts. This approach is especially useful for highly diluted single-site systems in which identification of the active sites and elucidation of the surface chemistry is very challenging. Furthermore, this work reveals that, in addition to their promising selective hydrogenation properties, SAAs provide the ultimate limit for the most efficient use of costly catalytic elements such as Pt.

\section{Methods}

Ultra-high vacuum studies. STM and TPD/R experiments were performed in three separate ultra-high vacuum chambers with base pressures $<1 \times 10^{-10} \mathrm{mbar}$ $\mathrm{Cu}(111)$ single crystals were clean with cycles of $\mathrm{Ar}^{+}$sputtering $(1.5 \mathrm{keV}, 15 \mu \mathrm{A})$ and annealing to $700 \mathrm{~K}$. A flux-monitored EFM 3 electron beam evaporator (Focus $\mathrm{GmbH}$ ) was used to deposit Pt at a flux of $0.02 \mathrm{ML}$ per min onto $\mathrm{Cu}(111)$ held at $380 \mathrm{~K}$. STM images were acquired on a variable-temperature STM and a LT-STM (Omicron NanoTechnology) with the sample held at 30 or $5 \mathrm{~K}$, respectively. Atomic resolution was obtained at tunnelling conditions of 150-200 nA and biases between 0.01 and $0.05 \mathrm{~V}$. $\mathrm{Pt} / \mathrm{Cu}(111)$ samples were exposed to $20 \mathrm{~L} \mathrm{H}_{2}(99.9 \%$ Airgas) at $80 \mathrm{~K}$ and then cooled to $5 \mathrm{~K}$ for imaging with LT-STM. STM images of $\mathrm{H}$ adatoms were obtained at non-perturbative conditions of $30 \mathrm{pA}$ and $30 \mathrm{mV}$. TPD traces were obtained in a chamber equipped with a quadrupole mass spectrometer. $\mathrm{Pt} / \mathrm{Cu}(111)$ surfaces were cooled to $85 \mathrm{~K}$ with liquid nitrogen and exposed to $\mathrm{H}_{2}$ (99.9\% Airgas), $\mathrm{CO}$ ( $99.99 \%$ Airgas), 1-butene ( $\geq 99 \%$ Aldrich) and/or 1,3-butadiene ( $\geq 99.5 \%$ Aldrich). Exposures are quoted in Langmuir $\left(1 \mathrm{~L}=1 \times 10^{-6}\right.$ torr $)$. TPD/R measurements were performed with a linear heat ramp $1 \mathrm{Ks}^{-1}$. The integrated areas under the TPD traces are proportional to the number of molecules desorbing from the surface. $\mathrm{H}_{2}$ coverages were determined by the saturation coverage of $(1 \times 1) \mathrm{H}$ adsorbed on $5 \mathrm{ML}$ of $\mathrm{Pt}$, assuming that the surface terminates as $\mathrm{Pt}(111)$.

Synthesis and characterization. Pt/Cu NPs with different Pt loadings were synthesized using the GR method on the pre-reduced $\mathrm{Cu}$ NPs as described by Boucher et al. ${ }^{13}$ The $\mathrm{Cu}$ NPs were pre-formed and supported on $\gamma-\mathrm{Al}_{2} \mathrm{O}_{3}$ (ultra-pure grade $99.99 \%$, surface area $70-100 \mathrm{~m}^{2} \mathrm{~g}^{-1}$, Inframat Advanced Materials; heat-treated in air at $400{ }^{\circ} \mathrm{C}$ ), followed by calcination in air at $350{ }^{\circ} \mathrm{C}$. GR took place in aqueous solution under nitrogen protection with constant stirring and refluxing at $100^{\circ} \mathrm{C}$. Desired amounts of Pt precursor $\left(\mathrm{H}_{2} \mathrm{PtCl}_{6} \cdot x \mathrm{H}_{2} \mathrm{O}\right.$, Sigma-Aldrich) were added to a suspension of $\mathrm{Cu}$ NPs in an aqueous solution containing $\mathrm{HCl}(2 \mathrm{mM})$. After $20 \mathrm{~min}$, the resulting material was filtered, washed and dried in vacuum.

Aberration-corrected HAADF-STEM images of $\mathrm{Pt} / \mathrm{Cu}$ NPs were obtained at a nominal resolution of $0.07 \mathrm{~nm}$ using a JEOL 2200FS-AC STEM/TEM equipped with a hexapole corrector (CEOS GmbH, Heidelberg, Germany) at Oak Ridge National Laboratory. EDS imaging was conducted with a Bruker-AXS $30-\mathrm{mm}^{2}$ silicon-drift detector system and $\mathrm{Pt}, \mathrm{Cu}, \mathrm{Al}$ and $\mathrm{O}$ elemental maps were collected. The instrument was operated at $200 \mathrm{kV}$ for all imaging and EDS work.

X-ray absorption spectroscopy (XAS) measurements at the Pt- $\mathrm{L}_{\text {III }}$ edge were made at Argonne National Laboratory and Brookhaven National Laboratory in fluorescence mode at room temperature. All samples were reduced in $\mathrm{H}_{2}$ in situ before the measurements. Experimental and analysis details on the XAS are described in the Supplementary Methods.

Catalytic activity measurements. The selective hydrogenation activity of the catalysts was tested in a quartz-bed flow reactor for 1,3-butadiene hydrogenation with $400 \mathrm{mg}$ of catalyst diluted by $1.5 \mathrm{~g}$ of quartz particles. The as-synthesized $\mathrm{Pt} / \mathrm{Cu}$ catalysts were reduced in $\mathrm{H}_{2}$ at $350{ }^{\circ} \mathrm{C}$ for $4 \mathrm{~h}$ before the reaction, the $\mathrm{Cl}$ residues were removed in $\mathrm{H}_{2}$ as well. A gas mixture of 1.25\% 1,3-butadiene, $20 \%$ $\mathrm{H}_{2}$ and balance $\mathrm{He}$ (flow rate $=20 \mathrm{ml} \mathrm{min}^{-1}$, Gas hourly space velocity $(\mathrm{GHSV})=1,200 \mathrm{~h}^{-1}$ ) was introduced at $120^{\circ} \mathrm{C}$, followed by descending temperature testing. Gas chromatograph injections were done at each temperature after the temperature was stabilized for at least $10 \mathrm{~min}$. The exit gas stream was analysed in a flame ionization detector (FID) of a HP6890 gas chromatograph system equipped with a 30 -feet column (1/8 inches, filled with Sebaconitrile $20 \%$ Chromosorb Paw 80/100).

The activity tests with added propylene were conducted with a gas mixture of $2 \% 1$-3-butadiene, $20 \%$ propylene, $16 \% \mathrm{H}_{2}$ and balance $\mathrm{He}$ at a flow rate of $50 \mathrm{ml} \mathrm{min}^{-1}\left(100 \mathrm{mg}\right.$ catalyst, GHSV $\left.=12,000 \mathrm{~h}^{-1}\right)$. After the activity tests with ascending temperature up to $170^{\circ} \mathrm{C}$ (Supplementary Fig. 12), the long-time stability tests were performed isothermally at 160 and $145^{\circ} \mathrm{C}$ for $12 \mathrm{~h}$ at each temperature.

\section{References}

1. Stamenkovic, V. R. et al. Trends in electrocatalysis on extended and nanoscale Pt-bimetallic alloy surfaces. Nat. Mater. 6, 241-247 (2007).

2. Weitkamp, J., Jacobs, P. A. \& Martens, J. A. Isomerization and hydrocracking of $\mathrm{C}_{9}$ through $\mathrm{C}_{16} \mathrm{n}$-alkanes on Pt/HZSM-5 zeolite. Appl. Catal. B 8, 123-141 (1983).

3. Cheng, X. et al. A review of PEM hydrogen fuel cell contamination: impacts, mechanisms, and mitigation. J. Power Sources 165, 739-756 (2007).

4. Pettersson, L. \& Westerholm, R. State of the art of multi-fuel reformers for fuel cell vehicles: problem identification and research needs. Int. J. Hydrogen Energy 26, 243-264 (2001).

5. Thomas, J. M. The concept, reality and utility of single-site heterogeneous catalysts (SSHCs). Phys. Chem. Chem. Phys. 16, 7647-7661 (2014).

6. Zhai, Y. et al. Alkali-stabilized $\mathrm{Pt}-\mathrm{OH}_{\mathrm{x}}$ species catalyze low-temperature water-gas shift reactions. Science 329, 1633-1636 (2010).

7. Yang, M. et al. Catalytically active $\mathrm{Au}-\mathrm{O}(\mathrm{OH})_{\mathrm{x}}$-species stabilized by alkali ions on zeolites and mesoporous oxides. Science 1498-1501 (2014). 
8. Qiao, B. et al. Single-atom catalysis of $\mathrm{CO}$ oxidation using $\mathrm{Pt}_{1} / \mathrm{FeO}_{\mathrm{x}}$. Nat. Chem. 3, 634-641 (2011).

9. Yi, N., Si, R., Saltsburg, H. \& Flytzani-Stephanopoulos, M. Steam reforming of methanol over ceria and gold-ceria nanoshapes. Appl. Catal. B 95, 87-92 (2010).

10. Boucher, M. B., Goergen, S., Yi, N. \& Flytzani-Stephanopoulos, M. Shape effects in metal oxide supported nanoscale gold catalysts. Phys. Chem. Chem. Phys. 13, 2517-2527 (2011).

11. Besenbacher, F. et al. Design of a surface alloy catalyst for steam reforming. Science 279, 1913-1915 (1998).

12. Kyriakou, G. et al. Isolated metal atom geometries as a strategy for selective heterogeneous hydrogenations. Science 335, 1209-1212 (2012).

13. Boucher, M. B. et al. Single atom alloy surface analogs in $\mathrm{Pd}_{0.18} \mathrm{Cu}_{15}$ nanoparticles for selective hydrogenation reactions. Phys. Chem. Chem. Phys. 15, 12187-12196 (2013).

14. McCue, A. J., McRitchie, C. J., Shepherd, A. M. \& Anderson, J. A. $\mathrm{Cu} / \mathrm{Al}_{2} \mathrm{O}_{3}$ catalysts modified with Pd for selective acetylene hydrogenation. J. Catal. 319, 127-135 (2014)

15. Christensen, A. et al. Phase diagrams for surface alloys. Phys. Rev. B 56, 5822-5834 (1997).

16. Tyson, W. R. \& Miller, W. A. Surface free energies of solid metals estimation from liquid surface tension measurments. Surf. Sci. 62, 267-276 (1977).

17. Santana, J. A. \& Rösch, N. Hydrogen adsorption on and spillover from Au- and $\mathrm{Cu}$-supported $\mathrm{Pt}_{3}$ and $\mathrm{Pd}_{3}$ clusters: a density functional study. Phys. Chem. Chem. Phys. 14, 16062-16069 (2012).

18. Tierney, H. L., Baber, A. E. \& Sykes, E. C. H. Atomic-scale imaging and electronic structure determination of catalytic sites on $\mathrm{Pd} / \mathrm{Cu}$ near surface alloys. J. Phys. Chem. C 113, 7246-7250 (2009).

19. Lucci, F. R., Lawton, T. J., Pronschinske, A. \& Sykes, E. C. H. Atomic scale surface structure of $\mathrm{Pt} / \mathrm{Cu}(111)$ surface alloys. J. Phys. Chem. C 118, 3015-3022 (2014).

20. Yu, W., Porosoff, M. D. \& Chen, J. G. Review of Pt-based bimetallic catalysis: from model surfaces to supported catalysts. Chem. Rev. 112, 5780-5817 (2012).

21. Prinz, J. et al. Isolated Pd sites on the intermetallic PdGa(111) and PdGa(111) model catalyst surfaces. Angew. Chem. 124, 9473-9477 (2012).

22. Lonergan, W. W. et al. Low-temperature 1,3-butadiene hydrogenation over supported $\mathrm{Pt} / 3 \mathrm{~d} / \gamma-\mathrm{Al}_{2} \mathrm{O}_{3}$ bimetallic catalysts. Catal. Today 160, 61-69 (2011).

23. Qi, S., Yu, W., Lonergan, W. W., Yang, B. \& Chen, J. G. General trends in the partial and complete hydrogenation of 1,4-cyclohexadiene over Pt-Co, Pt-Ni and Pt-Cu bimetallic catalysts. Chem. Cat. Chem. 2, 625-628 (2010).

24. Greeley, J. \& Mavrikakis, M. Alloy catalysts designed from first principles. Nat. Mater. 3, 810-815 (2004)

25. Derrien, M. L. Selective hydrogenation applied to the refinging of petrochemical raw materials produced by steam cracking. Stud. Surf. Sci. Catal. 27, 613-666 (1986).

26. GBI Research. Polypropylene Global Market to 2020 - Developing Regions of Asia-Pacific and Middle East and Africa to Drive Polypropylene Market Growth http://gbiresearch.com (2013).

27. Mittendorfer, F., Thomazeau, C., Raybaud, P. \& Toulhoat, H. Adsorption of unsaturated hydrocarbons on $\mathrm{Pd}(111)$ and $\mathrm{Pt}(111)$ : A DFT study. J. Phys. Chem. B 107, 12287-12295 (2003)

28. Valcárcel, A., Clotet, A., Ricart, J. M., Delbecq, F. \& Sautet, P. Selectivity control for the catalytic 1,3-butadiene hydrogenation on Pt (111) and Pd (111) surfaces: Radical versus closed-shell intermediates. J. Phys. Chem. B 14175-14182 (2005).

29. Collins, D. M. \& Spicer, W. E. The adsorption of $\mathrm{CO}, \mathrm{O}_{2}$ and $\mathrm{H}_{2}$ on Pt. Surf. Sci. 69, 85-113 (1977)

30. Anger, G., Winkler, A. \& Rendulic, K. D. Adsorption and desorption kinetics in the systems $\mathrm{H}_{2} / \mathrm{Cu}(111), \mathrm{H}_{2} / \mathrm{Cu}(110)$ and $\mathrm{H}_{2} / \mathrm{Cu}(100)$. Surf. Sci. 220, 1-17 (1989).

31. Linke, R. et al. Interaction of hydrogen with $\mathrm{Cu}_{3} \mathrm{Pt}(111)$ : dissociation via isolated platinum atoms. Surf. Sci. 307 - 309, 407-411 (1994).

32. Fu, Q. \& Luo, Y. Catalytic activity of single transition-metal atom doped in $\mathrm{Cu}(111)$ surface for heterogeneous hydrogenation. J. Phys. Chem. C. 117, 14618-14624 (2013).

33. Jewell, A. D. et al. Quantum tunneling enabled self-assembly of hydrogen atoms on $\mathrm{Cu}(111)$. ACS Nano 6, 10115-10121 (2012).

34. Greeley, J. \& Nørskov, J. K. Large-scale, density functional theory-based screening of alloys for hydrogen evolution. Surf. Sci. 601, 1590-1598 (2007).

35. Diño, W., Kasai, H. \& Okiji, A. Dissociative adsorption dynamics of $\mathrm{H}_{2}$ at the atop- $\mathrm{Pt}$, atop- $\mathrm{Cu}$, and $\mathrm{Cu}-\mathrm{Pt}$ bridge sites of an ordered $\mathrm{Cu}_{3} \mathrm{Pt}(111)$ orientational effects. Appl. Surf. Sci. 169-170, 36-41 (2001).

36. Chen, B. et al. New developments in hydrogenation catalysis particularly in synthesis of fine and intermediate chemicals. Appl. Catal. A 280, 17-46 (2005).

37. Zaera, F. \& Somorjai, G. A. Hydrogenation of ethylene over platinum (111) single-crystal surfaces. J. Am. Chem. Soc. 106, 2288-2293 (1984).
38. Stacchiola, D., Azad, S., Burkholder, L. \& Tysoe, W. T. An investigation of the reaction pathway for ethylene hydrogenation on $\mathrm{Pd}(111)$. J. Phys. Chem. B 105, 11233-11239 (2001).

39. Guo, X. \& Madix, R. J. Selective hydrogenation and H-D exchange of unsaturated hydrocarbons on $\mathrm{Pd}(100)-\mathrm{p}(1 \mathrm{x} 1)-\mathrm{H}(\mathrm{D})$. J. Catal. 155, 336-344 (1995).

40. Brandt, B. et al. Isomerization and hydrogenation of cis-2-butene on Pd model catalyst. J. Phys. Chem. C. 112, 11408-11420 (2008).

41. Zhao, H., Welch, L. a. \& Koel, B. E. Site-blocking effects of preadsorbed H on $\mathrm{Pt}(111)$ probed by 1,3-butadiene adsorption and reaction. Surf. Sci. 603, 3355-3360 (2009).

42. Yoon, C., Yang, M. X. \& Somorjai, G. A. Hydrogenation of 1,3-butadiene on platinum surfaces of different structures. Catal. Lett. 46, 37-41 (1997).

43. Michalak, W. D., Krier, J. M., Komvopoulos, K. \& Somorjai, G. A. Structure sensitivity in Pt nanoparticle catalysts for hydrogenation of 1,3-butadiene: In situ study of reaction intermediates using SFG vibrational spectroscopy. J. Phys. Chem. C 117, 1809-1817 (2013).

44. Zhao, H. \& Koel, B. Hydrogenation of 1,3-butadiene on two ordered Sn/Pt(111) surface alloys. J. Catal. 234, 24-32 (2005).

45. Marcinkowski, M. D. et al. Controlling a spillover pathway with the molecular cork effect. Nat. Mater. 12, 523-528 (2013).

46. Schröder, U., Linke, R., Boo, J. \& Wander, K. Adsorption properties and formation of Pt/Cu surface alloys. Surf. Sci. 354, 211-217 (1996).

47. Lu, X., Chen, J., Skrabalak, S. E. \& Xia, Y. Galvanic replacement reaction: a simple and powerful route to hollow and porous metal nanostructures. J. Nanoeng. Nanosci. 221, 1-16 (2007).

48. Yamamoto, T. a., Nakagawa, T., Seino, S. \& Nitani, H. Bimetallic nanoparticles of $\mathrm{PtM}(\mathrm{M}=\mathrm{Au}, \mathrm{Cu}, \mathrm{Ni})$ supported on iron oxide: radiolytic synthesis and $\mathrm{CO}$ oxidation catalysis. Appl. Catal. A 387, 195-202 (2010).

49. Yang, M., Allard, L. F. \& Flytzani-Stephanopoulos, M. Atomically dispersed $\mathrm{Au}-(\mathrm{OH})_{\mathrm{x}}$ species bound on titania catalyze the low-temperature water-gas shift reaction. J. Am. Chem. Soc. 135, 3768-3771 (2013).

50. Peterson, E. J. et al. Low-temperature carbon monoxide oxidation catalysed by regenerable atomically dispersed palladium on alumina. Nat. Commun. 5, 4885 (2014).

51. Dobrovolná, Z., Kačer, P. \& Červený, L. Competitive hydrogenation in alkene alkyne - diene systems with palladium and platinum catalysts. J. Mol. Catal. A 130, 279-284 (1998).

52. Boitiaux, J. P., Cosyns, J. \& Robert, E. Liquid phase hydrogenation of unsaturatued hydrogcarbons on palladium, platinum and rodium catalysts. Appl. Catal. 32, 145-168 (1987).

53. Kolli, N. E. 1., Delannoy, L. \& Louis, C. Bimetallic Au-Pd catalysts for selective hydrogenation of butadiene: Influence of the preparation method on catalytic properties. J. Catal. 297, 79-92 (2013).

54. Zhao, H. \& Koel, B. E. Adsorption and reaction of 1,3-butadiene on $\mathrm{Pt}(111)$ and Sn/Pt(111) surface alloys. Surf. Sci. 572, 261-268 (2004).

55. Delannoy, L. et al. Selective hydrogenation of butadiene over $\mathrm{TiO}_{2}$ supported copper, gold and gold-copper catalysts prepared by deposition-precipitation. Phys. Chem. Chem. Phys. 16, 26514-26527 (2014).

\section{Acknowledgements}

We thank the Department of Energy (DE-FG02-05ER15730) (J. L., M. Y.) and the National Science Foundation (CBET-1159882) (F. L., J. L. 2013-2014) for the financial support of this work. M. M. thanks Tufts Chemistry for an Illumina Fellowship. J. L. thanks Prof. Terry Haas (Tufts University) for assistance with the EXAFS data analysis, Dr. Yong Zhang (MIT's Center for Material Science and Engineering) for his assistance with High resolution transmission electron microscopy (HRTEM, and Drs. Sungsik Lee (Argonne National Lab), Benjamin Reinhart (Argonne National Lab), Drs. Syed Khalid (Brookhaven National Lab), Nebojsa Marinkovic (Brookhaven National Lab) for their assistance with the in-situ XAS experiments. Aberration-corrected electron microscopy research at Oak Ridge National Laboratory was sponsored by the U. S. Department of Energy, Office of Energy Efficiency and Renewable Energy, Vehicle Technologies Office, Propulsion Materials Program.

\section{Author contributions}

F.R.L., J.L., M.F.-S. and E.C.H.S. designed the experiments, analysed the data and wrote the paper. F.R.L. and M.D.M. carried out surface science studies. J.L., M.Y. and L.F.A. carried out the nanoparticle experiments. All authors discussed the results and edited the manuscript.

\section{Additional information}

Supplementary Information accompanies this paper at http://www.nature.com/ naturecommunications

Competing financial interests: The authors declare no competing financial interests. 
Reprints and permission information is available online at http://npg.nature.com/ reprintsandpermissions/

How to cite this article: Lucci, F. R. et al. Selective hydrogenation of 1,3-butadiene on platinum-copper alloys at the single-atom limit. Nat. Commun. 6:8550 doi: $10.1038 /$ ncomms9550 (2015). (c) (i) This work is licensed under a Creative Commons Attribution 4.0 International License. The images or other third party material in this article are included in the article's Creative Commons license, unless indicated otherwise in the credit line; if the material is not included under the Creative Commons license, users will need to obtain permission from the license holder to reproduce the material. To view a copy of this license, visit http://creativecommons.org/licenses/by/4.0/ 